\title{
Optimal Standardized Ileal Digestible Arginine to Lysine Ratio for Japanese Quails in the Egg-Laying Phase
}

\section{-Author(s)}

\section{Tuesta GMR' \\ Viana GS" \\ Barreto SLT' \\ Muniz JCL' \\ Reis RS"II \\ Mencalha RN \\ Hannas MI}

Universidade Federal de Viçosa, Viçosa, Minas Gerais, Brazil.

" Universidade Estadual Paulista Júlio de Mesquita Filho, Jaboticabal, São Paulo, Brazil

III Universidade Federal de São João del Rei, São João del Rei, Minas Gerais, Brazil.

iv Universidade Federal de Lavras, Lavras, Minas Gerais, Brazil.

\section{Mail Address}

Corresponding author e-mail address Jorge Cunha Lima Muniz

Avenida Bruno Martinho, no 145, ap. 103, CEP. 36570-000. Viçosa, MG, Brazil.

Email: jorge.limamuniz@hotmail.com

\section{Eeywords}

Coturnix coturnix japonica, digestible amino acids, ideal protein.

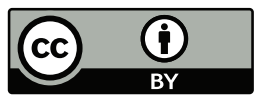

Submitted: 25/May/2017

Approved: 26/July/2017

\section{ABSTRACT}

This study was conducted to determine the optimal standardized ileal digestible arginine to lysine (SID Arg:Lys) ratio for Japanese quails in the egg-laying phase. A total of two hundred forty-five 35-weekold Japanese quails $(181 \pm 1.30 \mathrm{~g}$ initial body weight) were randomly assigned to five treatment groups with seven replicates of seven quails. Graded levels of L-Arginine were added to a basal diet in order to produce five SID Arg:Lys ratios (101, 106, 111, 116 and 121\%). Collected data were analyzed as one-way ANOVA and optimal ratio was estimated using polynomial regression model (linear and quadratic) based on performance traits. Statistical differences were considered for $p<0.05$. Graded SID Arg:Lys ratios did not affect performance traits assessed. Based on results, the SID Arg:Lys ratio of $101 \%$ is sufficient to warrant proper performance of Japanese quails in the egg-laying phase.

\section{INTRODUCTION}

Poultry are not able to synthetize arginine (Arg) themselves, and therefore, supplying adequate amounts of dietary Arg is essential to meet the bird nutritional requirements (D'Mello \& Lewis, 1971). Beyond playing its classical role of building blocks for body and feather protein synthesis, Arg participates on the biosynthesis of several molecules, such as creatine and polyamines (Khajali \& Wideman, 2010). In avian species, Argis involved in reproductive physiology (Grossman et al., 2002), since it is one of the components of avian neurohypophysial peptide arginine vasotocin, which among other functions, influences reproductive tract physiology by stimulating shell gland contractility and oviposition (Koike et al., 1988). Moreover, Arg participates in the pathway of nitric oxide synthesis (Jobgen et al., 2006), which modulates reproductive functions in poultry (Sundaresan et al., 2007 and Kumar \& Chaturvedi, 2008), regulating follicular development, ovulatory mechanisms, and egg production (Manwar et al., 2006).

Few is known about how limiting Arg is in diets compared with other essential amino acids, and contrary to lysine, methionine, threonine, valine and tryptophan, Arg is not available as afeed grade amino acid trade product. Perhaps due to such reason, few are the research efforts put forward establishing either poultry requirements for Argor its ideal relative ratio to lysine. Protein is widely recognized as the most expensive nutrient in poultry diets, though nutritionists tend to reduce protein content in practical diets with the purpose of saving feed cost, which, in some cases, may limit essential amino acid supply. Crystalline amino acid supplementation in low-protein diets offers several advantages in poultry production, such as reducing feed costs and nitrogen excretion in the environment (Franco et al., 2016). However, as aforementioned, the industrial production of feed-grade amino acids is limited to only few 
Tuesta GMR, Viana GS, Barreto SLT, Muniz JCL, Reis RS, Mencalha R, Hannas M
Optimal Standardized Ileal Digestible Arginine to Lysine Ratio for Japanese Quails in the Egg-Laying Phase amino acids, which frequently limit further reductions of dietary crude protein.

Establishing Japanese quail requirements for all essential amino acids would contribute to meet more precisely nutritional requirements. Since proposed, the ideal protein concept has been the most commonly used approach to formulate poultry diets, which must supply all amino acids at optimal ratios relative to dietary Lys content. Literature reports optimal SID Arg:Lysratios for Japanese quails of 116\% (Rostagno et al., 2011), 132\% (Silva \& Costa, 2009), and 126\% (NRC, 1994). Although such nutritional recommendations are important references, further studies are needed to update the nutritional requirements of Japanese quails. Reis et al., 2012 and Maurício et al., 2016 demonstrated that the optimal SID Arg:Lys ratios for Japanese quails are lower than the recommendations mentioned above. Therefore, this study was conducted to determine the optimal SID (standardized ileal digestible) Arg:Lys ratio for Japanese quails in the egglaying phase.

\section{MATERIALS AND METHODS}

All the procedures described below were previously approved by the institutional Animal Care and Use Committee of the Universidade Federal de Viçosa, Minas Gerais, Brazil (protocol number 38/2012).

\section{Husbandry, diets and experimental design}

A total of 245 35-to-44-week-old Japanese quails were selected from a local commercial flock according to body weight (181 \pm 1.30 grams), and randomly allocated to five treatments with seven replicates of seven birds each. Birds were housed in $25 \times 35 \times 15$ $\mathrm{cm}$ (length $\mathrm{x}$ width $\mathrm{x}$ height) stainless steel cages, equipped with an automatic feeder and a nipple drinker. Photoperiod was set at 16L:8D throughout the 9-week feeding trial, in which quails had free access to water and feed (mash form).Diets were formulated to be isonitrogenous (175.50 g CP/kg diet) and isocaloric (2,800 kcal ME/kg diet). All other nutrients were supplied to meet or exceed Rostagno et al. (2011) recommendations. The experimental treatments consisted of five diets with graded SID Arg:Lys ratios (101, 106, 111, 116,or 121\%), which were obtained by the graded supplementation of L-Arginine (0.00, 0.51, 1.01, 1.52 and $2.02 \mathrm{~g} / \mathrm{kg}$ diet) at the expense of L-Glutamic acid. The nutritional composition of the feed stuffs used to formulate basal diet were assumed to be as described by Rostagno et al. (2011). Crystalline amino acids were assumed to be $100 \%$ digestible. Since the objective of the current study was to determine Arg requirement as a ratio of Lys requirement, the basal diet was formulated to be first limiting in Arg and second limiting in Lys (Boisen, 2003). The suboptimal level of Lys chosen to formulate the basal diet corresponded to $92 \%$ of the level recommended by Rostagno et al. (2011).

\section{Performance and egg quality measure- ments}

All the eggs produced were daily recorded, whereas other performance and egg quality traits

Table 1 - Ingredients and calculated composition of the experimental diets on as-fed basis.

\begin{tabular}{|c|c|c|c|c|c|}
\hline \multirow[b]{2}{*}{ Item } & \multicolumn{5}{|c|}{ SID Arg:Lys, \% } \\
\hline & 101 & 106 & 111 & 116 & 121 \\
\hline \multicolumn{6}{|l|}{ Ingredient, g/kg } \\
\hline Corn & 359.51 & 359.51 & 359.51 & 359.51 & 359.51 \\
\hline Soybean meal & 238.82 & 238.82 & 238.82 & 238.82 & 238.82 \\
\hline Sorghum & 260.00 & 260.00 & 260.00 & 260.00 & 260.00 \\
\hline Wheat bran & 27.50 & 27.50 & 27.50 & 27.50 & 27.50 \\
\hline Soybean oil & 12.61 & 12.61 & 12.61 & 12.61 & 12.61 \\
\hline Limestone & 68.94 & 68.94 & 68.94 & 68.94 & 68.94 \\
\hline Dicalcium phosphate & 11.14 & 11.14 & 11.14 & 11.14 & 11.14 \\
\hline Salt & 3.33 & 3.33 & 3.33 & 3.33 & 3.33 \\
\hline Glutamic acid & 7.00 & 5.31 & 3.68 & 2.03 & 0.36 \\
\hline Corn starch & 1.00 & 2.18 & 3.31 & 4.46 & 5.62 \\
\hline L-Lysine $\mathrm{HCl}(79 \%)$ & 2.89 & 2.89 & 2.89 & 2.89 & 2.89 \\
\hline DL-Methionine (99\%) & 3.71 & 3.71 & 3.71 & 3.71 & 3.71 \\
\hline L-Threonine (98\%) & 0.42 & 0.42 & 0.42 & 0.42 & 0.42 \\
\hline L-Valine (99\%) & 0.35 & 0.35 & 0.35 & 0.35 & 0.35 \\
\hline L-Tryptophan (99\%) & 0.18 & 0.18 & 0.18 & 0.18 & 0.18 \\
\hline L-Arginine (99\%) & 0.00 & 0.51 & 1.01 & 1.51 & 2.02 \\
\hline Premix ${ }^{1}$ & 2.00 & 2.00 & 2.00 & 2.00 & 2.00 \\
\hline Choline chloride & 1.00 & 1.00 & 1.00 & 1.00 & 1.00 \\
\hline \multicolumn{6}{|l|}{ Calculated composition } \\
\hline Metabolizable energy, kcal/kg & 2,800 & 2,800 & 2,800 & 2,800 & 2,800 \\
\hline Crude protein, g/kg & 175.50 & 175.50 & 175.50 & 175.50 & 175.50 \\
\hline Calcium, g/kg & 30.99 & 30.99 & 30.99 & 30.99 & 30.99 \\
\hline Non-phytate phosphorus, g/kg & 3.23 & 3.23 & 3.23 & 3.23 & 3.23 \\
\hline Sodium, g/kg & 1.55 & 1.55 & 1.55 & 1.55 & 1.55 \\
\hline \multicolumn{6}{|l|}{ Digestible amino acids, $\mathrm{g} / \mathrm{kg}$} \\
\hline Lysine & 10.00 & 10.00 & 10.00 & 10.00 & 10.00 \\
\hline Arginine & 10.10 & 10.60 & 11.10 & 11.60 & 12.10 \\
\hline Methionine + cysteine & 8.20 & 8.20 & 8.20 & 8.20 & 8.20 \\
\hline Threonine & 6.00 & 6.00 & 6.00 & 6.00 & 6.00 \\
\hline Valine & 7.50 & 7.50 & 7.50 & 7.50 & 7.50 \\
\hline Tryptophan & 2.10 & 2.10 & 2.10 & 2.10 & 2.10 \\
\hline
\end{tabular}

'Provided per kilogram of diet: vitamin $A, 7,500 \mathrm{IU}$; vitamin $\mathrm{D}_{3}$ 2,000 IU; vitamin E, $10 \mathrm{IU}$; vitamin $\mathrm{K}, 1.80 \mathrm{mg}$; vitamin $\mathrm{B}_{1}, 1.5 \mathrm{mg}$; vitamin $\mathrm{B} 2,4.0 \mathrm{mg}$; nicotinic acid, $25 \mathrm{mg}$; pantothenic acid, $10 \mathrm{mg}$; vitamin B6, $1.7 \mathrm{mg}$; vitamin B12, $0.013 \mathrm{mg}$; folic acid, $0.50 \mathrm{mg}$; biotin, $0.05 \mathrm{mg}$; copper, $11 \mathrm{mg}$; iron, $55 \mathrm{mg}$; iodine, $1.10 \mathrm{mg}$; manganese, $77 \mathrm{mg}$; selenium, 0.33 $\mathrm{mg}$; zinc, $72 \mathrm{mg}$ and butylated hydroxytoluene, $0.1 \mathrm{~g}$. 
Tuesta GMR, Viana GS, Barreto SLT, Muniz JCL, Reis RS, Mencalha R, Hannas M

\section{Optimal Standardized Ileal Digestible Arginine to Lysine Ratio for Japanese Quails in the Egg-Laying Phase}

\section{Statistical analysis}

Each cage housing seven quails was considered as an experimental unit for statistical analysis. Data were analyzed as one-way ANOVA using the statistical software SAEG (SAEG, 2007). The optimal SID Arg:Lys ratio for each performance trait assessed was estimated by polynomial (linear or quadratic) regression model. Statistical significance was considered at $p<0.05$. The statistical model considered experimental treatment as fix effect: Yik $=\mu+$ SID Arg:Lys + eik. Where $Y_{i k}=$ dependent variable; $\mu=$ overall mean; SID Arg:Lys L $_{i}=$ standardized ileal digestible arginine to lysine ratios ( $\mathrm{i}$ $=101,106,111,116$ and $121 \%) ; \mathrm{e}_{\mathrm{ik}}=$ random error term.

\section{RESULTS AND DISCUSSION}

The evaluated SID Arg:Lys ratios (101, 106, 111, 116 and $121 \%$ )did not affect ( $p>0.05$ ) either performance (Table 2) or egg quality traits assessed (Table 3). Our outcomes are in agreement with Reis et al. (2012),

Table 2 - Production performance of Japanese quails in lay fed increasing SID Arg:Lys ratios.

\begin{tabular}{|c|c|c|c|c|c|c|c|c|}
\hline \multirow{2}{*}{ Item } & \multicolumn{5}{|c|}{ SID Arg:Lys ratios (\%) } & \multicolumn{2}{|c|}{ Effect } & \multirow{2}{*}{$\mathrm{SEM}^{3}$} \\
\hline & 101 & 106 & 111 & 116 & 121 & $L^{1}$ & $\mathrm{Q}^{2}$ & \\
\hline ADFI* (g/bird/day) & 25.65 & 26.40 & 26.22 & 26.26 & 25.77 & 0.99 & 0.19 & 0.45 \\
\hline Egg production (\%) & 84.89 & 85.67 & 84.89 & 85.89 & 82.84 & 0.99 & 0.16 & 3.05 \\
\hline Egg weight (g) & 11.49 & 11.47 & 11.55 & 11.69 & 11.53 & 0.99 & 0.15 & 0.48 \\
\hline Egg mass (g/bird/day) & 9.75 & 9.82 & 9.80 & 10.3 & 9.54 & 0.06 & 0.32 & 0.43 \\
\hline $\mathrm{FCR}^{*}$ (kg/dozen eggs) & 0.364 & 0.371 & 0.372 & 0.367 & 0.374 & 0.13 & 0.99 & 0.01 \\
\hline $\mathrm{FCR}(\mathrm{kg} / \mathrm{kg})$ & 2.64 & 2.69 & 2.68 & 2.62 & 2.71 & 0.11 & 0.99 & 0.11 \\
\hline
\end{tabular}

"ADFI: average daily feed intake; FCR: feed conversion ratio. 'Linear effect. ${ }^{2}$ Quadratic effect. ${ }^{3}$ Standard error of the mean.

Table 3 - Egg quality traits of Japanese quails in lay fed increasing SID Arg:Lys ratios.

\begin{tabular}{|c|c|c|c|c|c|c|c|c|}
\hline \multirow{2}{*}{ Item } & \multicolumn{5}{|c|}{ SID Arg:Lys ratios (\%) } & \multicolumn{2}{|c|}{ Effect } & \multirow{2}{*}{$\mathrm{SEM}^{3}$} \\
\hline & 101 & 106 & 111 & 116 & 121 & $\mathrm{~L}^{1}$ & $\mathrm{Q}^{2}$ & \\
\hline Albumen weight (g) & 7.24 & 7.27 & 7.26 & 7.46 & 7.27 & 0.99 & 0.99 & 0.15 \\
\hline Albumen percentage (\%) & 62.07 & 62.15 & 61.82 & 62.74 & 62.17 & 0.99 & 0.15 & 1.17 \\
\hline Yolk weight (g) & 3.50 & 3.49 & 3.55 & 3.51 & 3.49 & 0.99 & 0.99 & 0.08 \\
\hline Yolk percentage (\%) & 30.04 & 29.84 & 30.32 & 29.55 & 29.86 & 0.99 & 0.99 & 0.67 \\
\hline Eggshell weight (g) & 0.92 & 0.94 & 0.92 & 0.92 & 0.93 & 0.99 & 0.99 & 0.03 \\
\hline Eggshell percentage (\%) & 7.89 & 8.01 & 7.86 & 7.71 & 7.97 & 0.99 & 0.19 & 0.23 \\
\hline Specific gravity $\left(\mathrm{g} / \mathrm{cm}^{3}\right)$ & 1.073 & 1.074 & 1.073 & 1.072 & 1.073 & 0.99 & 0.99 & 0.01 \\
\hline
\end{tabular}

'Linear effect. ${ }^{2}$ Quadratic effect. ${ }^{3}$ Standard error of the mean.

who did not observe any effects of SID Arg:Lys ranging between 116 and $136 \%$ on the performance and egg quality traits of Japanese quails. This finding suggests that the optimal SID Arg:Lys ratio required by Japanese quails in the egg-laying phase is lower than ratios evaluated herein, and lower than those recommended by Rostagno et al. (2011) (116\%), Silva \& Costa (2009) $(132 \%)$ and the NRC (1994) (126\%). Similarly, Santos
(2010) did not report any performance or egg quality differences in Japanese quails fed $82 \%$ or $152 \%$ Arg:Lys ratios. Therefore, although the outcomes of those dose-response studies indicate the minimal SID Arg:Lys ratio studied as optimal, further research must be conducted. The establishment of the minimum amount of Arg required to meet maintenance purposes and egg protein synthesis demand could contribute to 
Tuesta GMR, Viana GS, Barreto SLT, Muniz JCL, Reis RS, Mencalha R, Hannas M
Optimal Standardized Ileal Digestible Arginine to Lysine Ratio for Japanese Quails in the Egg-Laying Phase formulate diets with a lower crude protein content, resulting reductions in feed cost and nitrogen excretion.

Amino acid requirements are strongly influenced by sex, age, genetic strain, environmental temperature and health status. However, feedstuffs included in diet formulation and some nutrients may also affect amino acid requirements. In studies conducted to determine poultry requirements for Arg, dietary Lys content must be considered, since antagonisms between both amino acids affect requirements (Lewis et al., 1963; D'Mello \& Lewis, 1970). Dean and Scott (1968) reported that broiler performance was impaired due to excessive Lys intake. According to the same authors, extra crystalline Arg supplementation in high-Lys diets alleviated such detrimental effects. Arginine and Lys are basic amino acids, and therefore, share the same intestinal uptake system (Closs \& Mann, 2000). Considering that Lys concentration affects Arg absorption (D’Mello \& Lewis, 1970), excessive Arg content may also limit Lys uptake. In the current study, it was observed that increasing Arg:Lys ratios did not compromise the performance or egg quality traits of Japanese quails. However, contrary to our findings, Maurício et al. (2016) observed a linear decrease egg production when Japanese quails were fed SID Arg:Lys ratios ranging from 106 to 146\%, showing detrimental effects of excessive Arg supply on the performance, and that a 106\% SID Arg:Lys ratio warrants proper quail performance.

Impairments in performance of birds fed high dietary Lys levels may be also attributed to changes in the activity of the enzymes involved in Arg metabolism. The most classical example of lysine-arginine antagonism is the increase in kidney arginase activity, resulting in Arg catabolism (Silva et al. 2012). Excessive Lys has been also shown to influence the activity of arginine:glycine amidinotransferase (AGAT; Silva et al. 2012), which is involved in the synthesis of guanidinoacetic acid (GAA) in poultry liver. Guanidinoacetic acid is required in creatine biosynthesis pathway (Jung et al. 2013). Its role in the nutrition of Japanese quails in the egg-laying phase was recently reported by Murakami et al. (2014), who observed a linear increase in GAA and creatine contents in the egg of meat-type quail breeders in response to increasing GAA supplementation. Although breeder performance was not affected by GAA, the aforementioned authors observed improvement the performance of the offspring of GAA-supplemented breeders.

Considering the interactions between Lys and Arg, Lys levels different from that supplied in the current study may produce different estimates of the ideal SID Arg:Lys ratio. Despite not establishing the optimal SID
Arg:Lys ratio for Japanese quails, our results support the hypothesis that the optimal SID Arg:Lys ratios reported in literature for Japanese quails are excessive, and therefore maybe reduced. Hence, crude protein could be potentially reduced, resulting in benefits like the decrease in feed cost and the mitigation of nitrogen excretion in environment. We suggest that further studies be designed with lower levels of Arg than the studied herein with a wide range between the lower and higher levels under study. Based on the performance and egg quality results, SID Arg:Lys ratio of $101 \%$ is sufficient to warrant proper performance and egg quality of Japanese quails in the egg-laying phase.

\section{ACKNOWLEDGEMENTS}

The authors would like to thank CAPES, CNPq, and FAPEMIG for providing the financial support that allowed the conduction of the current research.

\section{REFERENCES}

Boisen S. Ideal dietary amino acid profiles for pigs. In: D’Mello JPF, editor. Amino acids in animal nutrition. Wallingford: CABI Publishing; 2003. p.157-168.

Dean WF, Scott HM. Ability of arginine to reserve the growth depression induced by supplementing a crystalline amino acid diet with excess lysine. Poultry Science 1968;(47)1:341-353.

D'Mello JPF, Lewis D. Amino acid interactions in chick nutrition. 1. The interrelationship between lysine and arginine. British Poultry Science 1970;(11)3:299-311.

D'Mello JP, Lewis D. Amino acid interactions in chick nutrition. 4. Growth, food intake and plasma amino acid patterns. British Poultry Science $1971 ; 12(3): 345-358$.

Franco SM, Tavernari FC, Maia RC, Barros VRSM, Albino LFT, Rostagno H, et al. Estimation of optimal ratios of digestible phenylalanine + tyrosine, histidine, and leucine to digestible Lys for performance and breast yield in broilers. Poultry Science 2016;(19)9:1-9.

Grossman R, Jurkevich A, Kohler A. Sex dimorphism in the avian argininevasotocin system with special emphasis to the bed nucleus of the stria terminalis. Comparative Biochemistry and Physiology A 2002;(131)4:833-837.

Koike TI, Shimada K, Cornett LE. Plasma levels of immunoreactive mesotocin andvasotocin during oviposition in chickens: relationship to oxytocic action of the peptidesin vitro and peptide interaction with myometrial membrane binding sites. General and Comparative Endocrinology 1988;(70)1:119-126.

Maurício TV, Vargas Junior JG, Souza MF, Barboza WA, Nunes LC, Soares RTRN, et al. Digestible arginine concentrations in the diet of Japanese quails. Semina: Ciências Agrárias 2016;(37)4:2453-2462.

NRC - National Research Council. Nutrient requirements of pPoultry. $9^{\text {th }}$ ed Washington: National Academy Press;1994.

Nesheim MC. Kidney arginase activity and lysine tolerance in strains of chickens selected for a high or low requirement for arginine. Journal of Nutrition 1968;(95)1:79-87. 
Tuesta GMR, Viana GS, Barreto SLT, Muniz JCL, Reis RS, Mencalha R, Hannas M Lysine Ratio for Japanese Quails in the Egg-Laying Phase
Reis RS, Barreto SLT, Abjaude WS, Dutra DR, Santos M, Paula E. Relationship of arginine with lysine in diets for laying Japanese quails. Revista Brasileira de Zootecnia 2012;(41)1:106-110.

Rostagno HS, Albino LFT, Donzele JL, Gomes PC, Oliveira RF, Lopes DC, et al. Brazilian tables for poultry and swine: composition of feedstuffs and nutritional requirements. $3^{\text {rd }}$ ed. Viçosa: UFV; 2011.

SAEG. Sistema de Análises Estatísticas e Genéticas. Versão 8.0. Viçosa: Universidade Federal de Viçosa; 2007.

Santos GC. Níveis de valina, isoleucina e arginina em dietas com baixo nível proteico para codornas japonesas em postura [thesis]. Botucatu (SP): Universidade Estadual Paulista; 2013.
Lewis D, Smith GH, Payne CG. Arginine in poultry nutrition. 1. Dietary requirement for arginine. British Journal of Nutrition 1963;(17)1:415431.

Silva JHV, Costa FGP. Tabelas para codornas japonesas e européias: tópicos especiais, composição de alimentos e exigências nutricionais. $2^{\text {nd }}$ ed. Jaboticabal: FUNEP; 2009.

Thompson R, Hamilton RMG. Comparison of the precision and accuracy of the flotation and archimedes' methods for measuring the specific gravity of eggs. Poultry Science 1982;(61)8:1599-1605. 
